\title{
Maintaining Reputation through Media Relations A Qualitative Analysis in Local Government of Madiun City
}

\author{
Desti Erma Susanti \\ Communication Study Program \\ Faculty of Social and Political Sciences \\ Universitas Sebelas Maret \\ Surakarta, Indonesia \\ destimaa27@gmail.com
}

\author{
Andre Rahmanto \\ Faculty of Social and Political Sciences \\ Universitas Sebelas Maret \\ Surakarta, Indonesia
}

\begin{abstract}
Public relations practitioners are the "bridges" between government and society who have a responsibility to communicate information to the society more quickly, precisely and accurately. Public relations practitioners, as a source of information in the processing and delivering the information, provide effective space for the media to continue the information. However, after the arrest of the Head of Region by the Corruption Eradication Commission, public relations practitioners are required to work harder to restore public confidence to the Regional Government. One of the stakeholders becoming the concern to public relations practitioners to restore reputation is the mass media. It cannot be denied that the power of the media which is able to mimic an opinion with the setting agenda they create will affect the reputation of an organization. Public relations practitioners, as a source of information in the processing and delivering the information, provide effective space on the media to continue as well as process the information. This research is an effort to know the strategy of public relations practitioner of Madiun Municipal Government in maintaining reputation of the City Government in front of audience especially the mass media. This research uses descriptive qualitative method by using interview technique. The research findings indicated that the strategy of public relations practitioner of Madiun Municipal Government was performed through media relations activity which is able to control the news circulating in society so that the reputation can be maintained.
\end{abstract}

Keywords - media relations; strategy of public relations practitioner; reputation

\section{INTRODUCTION}

Public relations practitioners of a governmental organization and corporate institutions play a very important role. In their activities, public relations practitioners carry out management functions in the terms of persuasive, effective and efficient information and communication to create a harmonious relationship with the public through various means of public relations to maintain a positive reputation. Public relations practitioners are needed because of the emergence of the developing organizational dynamics, inter-organizational competition, and public demand for services, public expectations of information needs, the number of critical society and the increasing influence of the media on the formation of public opinion.

Public relations practitioners play a role in creating mutual understanding and are responsible for providing information, educating, convincing, reaching for sympathy and generating public interest. In addition, in a governmental organization (local government), public relations practitioners are not only a mouthpiece or a voice from local government leaders, but are a creative liaison in conveying ideas, values and truths from both government and society. The role of the public relations practitioner is two-way orientations namely inward and outward orientations [1].

As "the person in the middle", your credibility, personality, writings, and verbal responses are central, in part, to good or bad news coverage, the public image of your agency, and the successful execution of your public relations. [2]. Public Relations practitioners are required to always develop in all things, especially in the terms of information and communication technology (ICT).

A public relations practitioner, in preaching or delivering news/information to the public, must be faster, precise and accurate. The implementation is not effective if it is performed manually or by communicating directly because it takes a long time and costs greatly. Therefore, public relations practitioners need the mass media to reach audiences in large quantities simultaneously.

The success of a public relations practitioner is largely determined by the mass media. Public relations practitioners, as a source of information in the processing and delivering the information, provide an effective space for the media to continue the information. However, it should be noted that the media are able to mimic an opinion with the setting agenda they create. With such tremendous power, mass media is able to build and destroy the order of a government. Thus, a good relationship between public relations practitioners and the media to maintain the image and reputation of an organization is needed.

Media and press relations is a supporting tool or media of cooperation for the benefit of the publication and publicity 
process of various work program activities or for the smooth communication activities of public relations practitioners with the public. Due to the role of media and press relations in public relations that can be a channel in conveying the message, the efforts to increase awareness and information or publication from the public-relations publication party become the top priority. This is because one function of the press is the power to form opinions (power of opinion) that is very effective through mass media [1].

After the arrest of the Madiun Regional Head by the Corruption Eradication Commission (KPK), good media relations became a priority for the Madiun Municipal Government to maintain a good reputation. Public relations practitioners of Madiun Municipal Government at the Office of Communications and Informatics carry out media relations activities to provide confidence to the community through positive information on the media. In addition, the cooperation between mass media or the press will also generate high positive publicity.

Some research findings have given contributions to the authors. A research, conducted by Mohd Yahya Mohamed Ariffin, Jessica Ong Hai Liaw, Zahimi Zainol Abidin, Noor Azmi Mohd Zainol and Mohammad Daud Johari [3] in Malaysia, described the importance of media relations resources. As a result, all media managers agree that in the practice of a relationship, the media is vital to enhancing the effectiveness of dissemination to a country. Moreover, it becomes something important and interesting to analyze about how the strategy of public relations practitioners in maintaining reputation through media relations at the Office of Communications and Informatics of Madiun Municipal Government. This article conducts a qualitative analysis with a problem analysis study which focuses on providing services in the implementation of media relations. Specifically, this article discusses: (1) how does the strategy of public relations practitioners maintain reputation? (2) how do public relations practitioners engage in media relations activities?

\section{THEORETICAL FRAMEWORK}

\section{A. Framework}

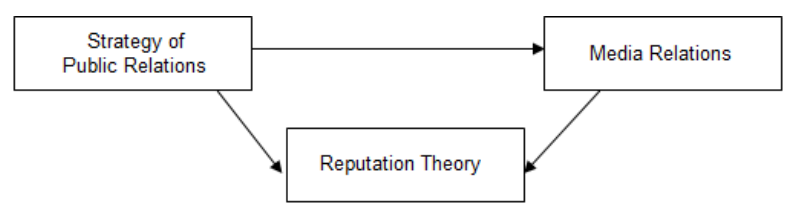

Fig. 1. Strategy of Public Relations

Media relations are used as one of strategy approaches toward the media. In this case, the researchers have a framework on the strategy of public relations of Madiun Municipal Government by maintaining good relations with the media to realize the achievement of a positive reputation in the Madiun Municipal Government.

\section{B. Theories}

\section{1) Reputation}

According to Fomburm, reputation begins with corporate identity as the first point which is reflected through the company's name (logo) and other display such as annual reports, brochures, product packaging, office interiors, employee uniforms, advertisements, and media coverage of the company, written and audio visual materials [4].

The positive strength and reputation of the company (institution or government) is the job of every public relations practitioner. Morley defines the management of a company's reputation (institution or government) as follows: an orchestra on the initiatives of public relations practitioners designed to promote or protect the importance of a brand, including the company's reputation (institution or government).

Reputation will be good or bad, strong or weak depending on the quality of strategic thinking and management commitment to achieve the established goals and the skill and energy with all components of the program that are going to be realized and communicated.

Regarding to the definition of reputation above, if a company has a good reputation, corporate profits will increase. Similarly, for a government issuing a variety of policies, if it has a good reputation then people's support for the government will continue to increase [4].

According to Fombrun and Van Riel, the reputation is:

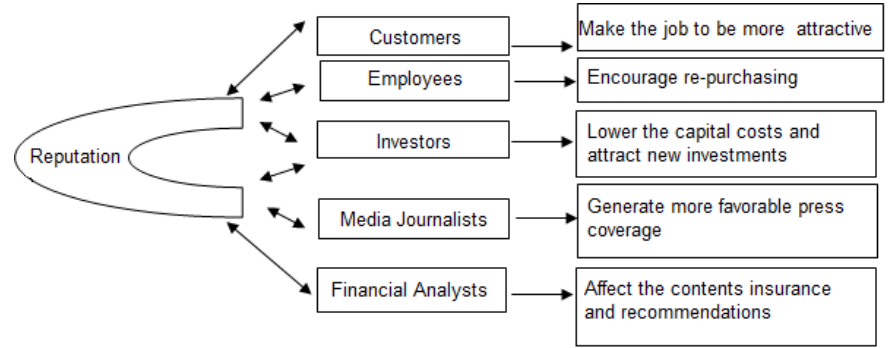

Fig. 2. Reputation, according to Fombron and van Riel. Source: Handbook of Public Relations [5].

Basically, managing the reputation of a government in keeping its reputation in the eyes of the people is not much different from the management of a company's reputation (profit). In this case, the institutions or government (nonprofit) put forward the importance of the image of the institution or government through various policies in accordance with the aspirations of the people so as to bring up a good reputation that eventually makes people loyal and support the government.

To maintain and enhance reputation, the government does not "sell" products or services, but a policy that combines top down (government) and bottom up (people) interests through effective communication or public relations activities [4].

\section{2) Strategy of Public Relations}

Ahmad S. Admanputra, MA, MS, public relations expert, in a workshop script entitled Public Relations Strategy, 1990 [1] mentioned that the meaning of strategy is an integrated part of a plan, while the plan is the product of a planning in which the 
planning is ultimately one of the basic functions of the management process. It was also mentioned about the definition of a public relations strategy which means "the optimal alternative chosen to be pursued to achieve public relations objectives within the framework of a public relations plan”.

The strategy of public relations is formed through two closely related components. The first stage includes the target component, i.e. the stakeholders and the public who have the same interests. These general targets are structurally and formally narrowed through segmentation efforts based on "to what extent the goal holds the common opinion, the potential for polemics and influence for the future of the organization and products that are specifically targeted”. The specific objective here is the target public.

The second stage, the components of the means, which serve to direct these three possibilities toward positions or beneficial dimensions through the "The 3-C's option" (Conservation, Change and Crystallization) pattern from the segmented stakeholders to the target public [1], are:

TABLE I. THE 3-C OPTIONS

\begin{tabular}{|l|l|l|}
\hline & Components & Strategies of Public Relations \\
\hline 1 & Conservation & Against an active opinion - Pro (Proponent) \\
\hline 2 & Change & Against an active opinion - Contra (Opponent) \\
\hline 3 & Crystallization & Against a passive opinion (Un-committed) \\
\hline
\end{tabular}

Source: Concepts and Applications of Public Relations Management and

Communication Media [1].

\section{3) Media Relations}

Media relations are one of the public relations activities in providing information to the public to gain public support and trust. Another term for media relations is press relations in which it fosters good relationship with the press that manages print media (newspapers and magazines), electronic media (radio and television), and online mass media (online newspaper, online magazine, digital radio, digital television) [4].

According Jefkins, the definition of press relations or media relations is an attempt to achieve maximum loading or broadcasting of a message or information (from public relations) in shaping knowledge and understanding of the organization or company [4].

Media relations activities will bring enormous effects when it is performed using the right working principles. According to Frank Jefkins, in implementing good media relations, public relations practitioner must pay attention to the followings [6]: (1) Understand and serve the media at all times. It can be performed by understanding who and how the mass media is. One way that can be performed to understand the media is to understand how media scape of the mass media; (2) Build a reputation as a trustworthy media organization. Public relations practitioners should be prepared to provide and supply materials that are accurate at anywhere and anytime. Thus, mutual reciprocal communication will be more easily created and maintained; (3) Provide copies of sufficient and accurate information. It is performed by providing a good, interesting and clear photographic reproduction by utilizing the development of ICT; (4) Cooperate in the provision of information materials. For example, a public relations practitioner and journalist can work together in preparing for an interview or press conference with certain public figures; (5) Provide verification facilities. Public relations practitioners also need to give journalists the opportunity to verify (prove the truth) of every news item they receive; (6) Build a solid personal relationship with the media. A solid and positive personal relationship will only be created and maintained based on the openness, honesty, cooperation and mutual respect for each other's professions.

Rhenald Khasali [6] introduced several stages before and during media relations that consist of: (1) Identifying the crisis. To identify a crisis, a public relations practitioner needs to conduct a research. When the crisis occurs quickly, the research must be conducted informally and quickly; (2) Analyzing the crisis. Prior to communicating, a public relations practitioner must perform an analysis of the input he/she obtained. This analysis is the work conducted behind the desk using the expertise skill in reading the problem. The analysis carried out has a wide range of interrelated analyzes; (3) Isolating the crisis. Crisis is a disease. Sometimes it can also be interpreted as more than just an ordinary illness. Therefore, to prevent the crisis from spreading more broadly, it must be isolated and quarantined before taking any serious action; (4) Determining the choice of strategy in dealing with crisis. Before taking communication steps to control the crisis, the determination of generic strategy needs to be performed. There are three generic strategies to handle the crisis, namely: a) Defensive Strategy. The steps taken include stalling time; not doing anything (inaction or low profile) and fortify themselves strongly (stone walling); b) Adaptive Strategy. The steps taken include broader issues such as changing policies, operational modifications, compromise, and aligning images. c) Dynamic Strategy. This strategy is nearly macro and may result in changing the company's characters. The options are mergers and acquisitions, new investments, selling stocks, launching new products or pulling old product circulation, holding the power, and throwing new issues to distract attention; (5) Running a control program. The control program is the implementation step that is carried out toward the generic strategy that has been formulated. Generally, generic strategies can be formulated long before the crisis arises, namely as a guidance for executives to take definite steps. Unlike generic strategies, control programs are usually arranged in the field when a crisis occurs. Implementation of controls is applied to companies (along with branch companies), industries (combined business), communities, and company divisions.

\section{RESEARCH METHOD}

This research used descriptive qualitative method. Descriptive qualitative method aims to systematically describe the facts or characteristics of a particular population or a particular field in a factual and accurate way. According to Sugiyono (2013), qualitative research is used to examine the condition of natural objects in which the researchers act as the key instruments. Data collection techniques are conducted using data triangulation (combined), the data analysis is inductive and qualitative research results emphasize the 
meaning of generalization. This research only describes the situation or event. It does not seek or explain the relationship of something and it does not test hypotheses or make predictions. Descriptive research often produces what Seltiz, Wrightsman, and Cook refer to as research that has stimulating insight. This research is conducted by going to the research field without being burdened or directed by theory [7].

The research subjects are public relations practitioners at the Office of Communications and Informatics of Madiun Municipal Government. The research data were collected by interview. Interview is a conversation between the researcher (someone who tries to collect the information) and the informant (someone who is assumed to have important information about particular object.According to Berger, the interview is a method data collection used to obtain information directly from the source.In conducting interviews to collect the information from the source, the researchersused in-depth interview technique. In-depth interview, according to Kriyantono [8], is an intensive and mostly unstructured interview to get qualitative information deeply.

\section{DisCUSSIONS}

\section{A. Strategy of Public Relations of Madiun Municipal Government in Building Media Relations}

Based on the description of its duties and functions in the field of Information and Public Communications Management, the public relations practitioner of Madiun Municipal Government is in charge of supplying media relations services that have been well planned before. The strategy of public relations activities is directed at the efforts in making various approaches to media managers so that the information can be broadcasted appropriately and received positive feedback in order to maintain the reputation from the society.

A good relationship with the media is built as an appropriate communication strategy, i.e.a way conducted for the smooth communication between public relations with the media. The good relationship, in this case, is the good relationship created between public relations practitioners with media institutions and between public relations practitioners with journalists.

The proper methods and strategies used by public relations practitioners of Madiun Municipal Government to create and build good relationships with media institutions and journalists will influence the success of publicity that has been conducted before. Messages and information submitted by public relations practitioners, both in the form of news and advertisements will be responded well by media institutions and journalists. As a result, messages submitted by public relations to the media will be published to the public appropriately.

\section{B. Media Relations Activities of Public Relations of Madiun Municipal Government}

To support the success of the media relations strategy used by Madiun Municipal Government, the running media relations are not only in written form. By the implementation of media relations program on the public communication management section, there are also social relations activities on the media including:

\section{1) Press Conferences}

The existing press conferences held by Madiun Municipal Government have involved 50 local and national media aiming to deliver a statement or information with the expectation that the news will be broadcasted widely. It activity is also implemented as a means to launch new products, deliver policies related to public information needs, clarify and control the circulating news as well as improve the image and reputation. The press conference is a routine activity held every month in place that has been prepared beforehand. However, there are also press conferences held unexpectedly at makeshift place.

\section{2) Press Reception}

The press day is an activity commemorated by Indonesian press once a year which falls on February 9th. Madiun Municipal Government also took part in the celebration of National Press Day as a form of press reception activities. Surely, this activity is conducted as a form of closeness and government attention to the press people who have worked with Madiun Municipal Government. This event is also used as a moment of appreciation to prove that the media is a competent media in publication and news, not fake one. It shows the audience that the media performance is real. In addition, it aims to provide motivation to media workers to further enhance the profession as a journalist and increase the spirit to remain in synergy with MadiunMunicipal Government.

\section{3) Journalistic Visit}

Journalistic visit is held once a year at the end of the year with the aim of knowing the media competence. Media competence is one of them can be seen from the oplage (print media), the number of visitors (online media) and rating (television and radio media). It will also determine the cooperation of local government in the interest of publication and information of work program, policy to be implemented by Madiun Municipal Government in the next year. In addition to discuss and recognize media institutions, this journalistic visit is also to determine whether the media can be the right channel to deliver the message to the public.

According to the Section Head of Public Communications Management, in an interview session, he highlighted that emotional attachment and respect for the media visited will have an impact on the support of any information that are publicly submitted to the public. 


\section{4) Press Tour}

This activity involves media workers conducted every once a year. The form of activities is a comparative study to a city where the government has a positive image in the community or to a credible media and then added with the purpose of tourist sites. In these activities the media crew was invited to discuss in order to motivate and improve the public relations element with the media and establish intimacy of media workers. Through this tour press, it can be seen that public relations with media is mutually beneficial and aimed to avoid miss communication between Madiun City Government and media.

\section{5) Media Event}

Various activities implemented by Madiun Municipal Government always involve the media. Activities scheduled to be attended by the Mayor and Deputy Mayor or activities involving the wider community will be informed to the journalists the day before. In these activities, the media were given the opportunity to cover and attend a friendly banquet. Besides, as a means of publication, it also becomes a form of public relations coordination in providing information materials.

\section{Evaluation Stages of Public Relations of Madiun Municipal Government}

Evaluation stages of public relations of Madiun Municipal Government are performed in the form of monitoring and media analysis service on online media and print media. Media monitoring and analysis services are carried out by analyzing: (1) The news volume, to find out which media contain news or information about the Madiun Municipal Government; (2) News category, to know the event about Madiun Municipal Government that is contained in the media; (3) Nature of news, to know the nature of positive, negative, and neutral news; (4) Quantity of news (media share), to know the amount of news appearing in the media; (5) Influences (news source) to find out how much a public figure becomes the source of the news.

\section{CONCLUSION}

To maintain its reputation, the practitioner of public relations of Madiun Municipal Government strives to be an effective "bridge" between government and society in delivering information to the public. Maintaining good media relations is a priority strategy by engaging in media relations activities. Some media relations activities that have been performed include press conference, press reception, journalistic visit, tour press, and media event. The final stage of the public relations strategy of Madiun Municipal Government is evaluation; namely by implementing monitoring and media analysis to know the media content circulating in the society.

\section{REFERENCES}

[1] R. Ruslan, Manajemen Public Reltions dan Media Komunikasi: Konsepsi dan Aplikasi [Concepts and Applications of Public Relations Management and Communication Media]. Jakarta: Rajawali Pers, 2012.

[2] G. N. M. Lee, The Practice Of Government Public Relations. Boca Raton: CRC Press Tailor \& Francis Group, 2012.

[3] M. Y. M. Ariffin, J. O. H. Liaw, Z. Z. Abidin, N. A. M. Zainol and M. D. Johari, "The Importance of Media Relations Resources in Malaysia," Medwell J. The Soc. Sci., vol. 11, pp. 6112-6119, 2016.

[4] E. Ardianto, Metodologi Penelitian untuk Public Relations Kuantitatif Dan Kualitatif [Research Methods for Public Relations: Quantitative and Qualitative]. Bandung: PT Remaja Rosdakarya, 2016.

[5] E. Ardianto, Handbook of Public Relations Pengantar Komprehensif [Handbook of Public Relations: Comprehensive Introduction]. Bandung: Simbiosa Rekatama Media, 2016.

[6] R. Darmastuti, Media Relations: Konsep, Strategi dan Aplikasi [Media Relations: Concept, Strategy, and Application]. Yogyakarta: Penerbit ANDI, 2012.

[7] J. Rakhmat, Metode Penelitian Komunikasi [Communication Research Method]. Bandung: PT. Remaja Rosdakarya, 2007.

[8] S. M. R. Kriyantono, Teknis Praktis Riset Komunikasi [Practical Technique Communication Research]. Jakarta: Kencana Prenada Media Group, 2006. 